\title{
Melodrama, Ascetic Modality, and Communist Self- fashioning: Mukhamukham and the Communist Hero in Malayalam Cinema
}

\author{
P. Muhammed Afzal \\ Assistant Professor, Department of Humanities and Social Sceinces, Birla Institute of \\ Technology and Science, Pilani (BITS Pilani), Pilani, Rajasthan, India-333031. ORCID ID: \\ oooo-0002-9989-6251. E-mail: muhammed.p@pilani.bits-pilani.ac.in
}

\begin{abstract}
This paper treats the Malayalam film Mukhamukham and the debates it engendered in the Kerala public sphere about the history and legacy of communism as an archive of passions and disavowals that have shaped the political subjectivities in contemporary Kerala and explores how the film offers a critique of the Left popular in Kerala. Through a critique of the ascetic modality of the communist hero, Mukhamukham offers a critique of the representative strategies through which the communist hero was produced in the early Left political melodramas in Malayalam, which have been a significant part of the Left's constitutive role in the construction of the domain of the popular in Kerala. The attempt in this paper is to read the film as one that, while marked by liberal prejudices, offers a critique of the Left popular and certain prevailing notions on the Left in Kerala. The paper explores how the film represents the figure of the revolutionary; and the shift from the melodramatic conventions of the construction of the revolutionary figure that Gopalakrishnan attempts in the film.
\end{abstract}

Keywords: melodrama, Left popular, Communist self-fashioning, Malayalam cinema, Kerala

\section{Introduction}

The Malayalam film Mukhamukham (Face to Face) directed by Adoor Gopalakrishnan, one of the leading figures of New Cinema in Malayalam, came out in 1984, engendering intense cultural and political debates in the Kerala public sphere on the history and legacy of the communist movement in the state and the film's portrayal of the same. While the film attracted strong reactions from the communist sympathizers, who saw it as an anti-communist film, the film was hailed by many as the true portrayal of the state of communism and politics in Kerala; or rather the film was understood as a story of the degeneration of the Left in Kerala. The film drew heavy criticism from the Communist Party in Kerala who reportedly threatened to have it banned from theatres (Swart, 2012, p. 274). Despite Gopalakrishnan's repeated assertion that Mukhamukham should not be seen as a political film (Gopalakrishnan, 1985, n.p), the film has widely been viewed and discussed as a political (anti-communist) film, by critics as well as the viewers.

Mukhamukham tells the story of the rise, disappearance, return, and fall of a communist leader. Sreedharan, the communist leader in the film, is a stranger who arrives

(c) AesthetixMS 2021. This Open Access article is published under a Creative Commons Attribution Non-Commercial 4.0 International License (http://creativecommons.org/licenses/by-nc/4.o/), which permits non-commercial re-use, distribution, and reproduction in any medium, provided the original work is properly cited. For citation use the DOI. For commercial re-use, please contact editor@rupkatha.com. 
in a small town from nowhere in the middle of the night and organizes the people in the local factory and emerges as a trade union leader giving the hope of emancipation to the people. He then mysteriously disappears and comes back after ten years as an ineffective alcoholic who becomes a burden for both the fractions of the party (which has by then split into two) and is eventually found killed under mysterious circumstances. The old image of Sreedharan is resurrected after his death when both the factions take out a procession in memory of Sreedharan.

The film is not just about the individual trade union leader; but a film on the communist movement in Kerala, as evidenced from the very beginning of the film. The precredit scenes provide the historical and geographical setting of the film. The film is set in central Kerala, south India. It can be assumed that the film is set in the Alappuzha region of south Kerala where the early trade union movements took shape. The rise of the communist movement in Kerala, its coming to power in 1957, and the split within the Communist Party provide the backdrop for the film. The film covers two periods: the first period covers the decade ending in 1955 when the Communist Party was gaining strength in Kerala after the ban on the party was lifted in 1952 . The second period covers the years from 1965, the immediate aftermath of the split within the Communist Party in 1964 and when the radical Left groups were taking root in the state. Sreedharan becomes the personification of the rise and fall of the Communist movement in the state. Thus, the trajectory of the communist movement in Kerala is central to the narrative of the film.

This paper treats Mukhamukham, while marked by liberal prejudices, as one that offers an important critique of certain notions prevalent in the Left project in Kerala and an opportunity to explore the centrality of melodrama in the communist project in Kerala. The paper explores how Mukhamukham offers a critique of the melodramatic nature of the communist project in Kerala. Through certain narrative strategies which have much in common with the narrative strategies of Swayamvaram, his first feature film, where the "real" is contrasted with the "fantasy" through intercuts, Adoor Gopalakrishnan attempts a critique of the melodramatic construction of the communist hero. In the film, the public "image" of the flawless, ascetic communist revolutionary is contrasted with what Gopalakrishnan perceives as the "real". It is by a division of the narrative into two parts, where one part presents the "subjective" narratives around the communist hero and the second part unravels the "real" through the "objective narrative" of the directorial voice that Gopalakrishnan attempts his critique of the communist hero.

I read Mukhamukham as a critique of the communist political melodramas of the 1960 s and 1970s, which constituted the Left popular, in which the construction of a Communist hero was central to the narrative. One may argue that the political melodramas of filmmakers such as Thoppil Bhasi, K S Sethumadhavan, participated in the construction of a communist hero through the melodramatic register. The melodramatic register enabled the creation of a Manichean moral polarity in which the hero triumphs at the end. In the early communist melodramas, we see the hero as representing the progressive values that the communist movement stood for, thus making the hero the representative of the 
imagined Malayali nation of rational subjects. It is worth exploring whether the progressive roles in communist melodramas like Mooladhanam, Ningalenne Communistakki, and Puthiya Akasam Puthiya Bhoomi played any role in fortifying the stardom of the Malayalam actor Sathyan.

In a "red film" like Ee Nadu (This Land), the polarity created is between the good communist and the bad communist in order to construct the ideal communist hero. The leading character of the film Ee Nadu is called Sakhavu (Comrade) Krishna Pillai, who can be seen as an assemblage of some of the communist leaders known for their political uprightness and selflessness such as P. Krishna Pillai, A.K. Gopalan, etc. P. Krishna Pillai, one of the founding members of the Communist Party in Kerala, who was simply known as Sakhavu (comrade) is often seen as the prototype of the Communist leader (Radhakrishnan, 2006, p. 146). I will come back to a discussion of how Gopalakrishnan's film attempts a critique of the communist hero and the revolutionary masculinity through the portrayal of the character of Sreedharan. It was in fact the portrayal of Sreedharan that led to much of the criticism about the film.

\section{Ascetic Modality and Revolutionary Masculinity}

As suggested before, it is through the critique of the figure of the revolutionary that Gopalakrishnan attempts a critique of the Left popular. In Mukhamukham, Gopalakrishnan continues the exploration of the crisis and the realignment of masculinity he had attempted in his earlier films like Kodiyettam (Ascent) and Elippathayam (The Rat Trap). Let us look at how Gopalakrishnan constructs the revolutionary masculinity of Sreedharan. The masculinity that is constructed is that of an ascetic. In a sequence in the first part of the film where Sreedharan introduces Lenin to Sudhakaran, Sreedharan tells Sudhakaran, pointing to the portrait of Lenin on the wall, "that is the great leader Lenin, the liberator of the proletariat". The introduction that is given to Lenin also serves as an introduction to Sreedharan. The image of Sreedharan that we get from other people's narratives in the first part of the film is that of a liberator of the proletariat whom the people pin their hopes on. As in the case of his other films, a male individual from the dominant Nair caste is the locus of transformation in Mukhamukham. The revolutionary masculinity of Sreedharan should thus be seen in the context of the crisis and realignment of Nair masculinity. It may be argued that the masculinity of Sreedharan does not remind us of the revolutionary masculinity of Fidel Castro or Che Guevara, which the communist hero in the so called "comrade films" that came out recently represents. Robin Jeffrey's observation that Communism in Kerala filled the ideological vacuum that was felt by the educated Nair youth after the social disintegration engendered by the end of matriliny becomes important in understanding the masculinity of Sreedharan.

In Mukhamukham, it is through the recollections of other characters that the image of Sreedharan emerges. The image of the revolutionary constructed through the narratives of other people is that of a selfless person. The revolutionary figure is also devoid of any markers that would reveal his identity. The spectator is not given any glimpse of his life 
before he reaches the small town. The image of Sreedharan as a revolutionary figure, as a liberator, someone equivalent to Lenin, is constructed from the point of view of Sudhakaran, the young communist, who was an adolescent when Sreedharan arrived at the small town and who, towards the end of the film, shows signs of moving towards a more radical communist politics. It is interesting to note that the image of the revolutionary Sreedharan that we see in the first part of the film is from the period before the Communist Party came to power in Kerala. Ratheesh Radhakrishnan has argued that the fact that Krishna Pillai died before the Communist Party came to power in Kerala has contributed to making him the prototype of revolutionary. In his study on the construction of a revolutionary masculinity around the figure of P. Krishna Pillai, Ratheesh Radhakrishnan argues that

In popular understandings of the history of the Communist Party in Kerala, the model of the revolutionary, epitomised by the figure of Krishna Pillai and other martyrs, represents a period of selfless political activity. This aspect of the model is made possible by the fact that these revolutionaries died before the Party came to power or became a respectable entity in Kerala. Even then the absence of a desire for power or other worldly matters should be understood as a significant part of the way the popular model of the revolutionary is circulated. .... It is also evident that the revolutionary is a man of few emotions and that he is represented as unapproachable and unrealisable (Radhakrishnan, 2006, pp. 155-156).

According to Radhakrishnan, an important aspect of Krishna Pillai's masculinity is in his disinterest in worldly temptations. He quotes an observation by one of Krishna Pillai's coprisoners that Pillai would never give in to the temptation of even a beedi while in jail. According to Radhakrishnan, "the two ideals, courage and disinterest in worldly pleasures combined with pride are the three motifs that build the image of Krishna Pillai in the early pages of the biography [of Krishna Pillai]" (p. 150). In Mukhamukham, we see Sreedharan telling Sudhakaran: "Personal relationships, pleasures, and selfish gains have to be given up by a Communist. Individual achievement is not our goal. On the contrary, it can only be a hindrance to overall social progress".

This conversation occurs in the film right after Sreedharan encounters Vilasini, Damodaran's sister, outside Damodaran's house. Vilasini asks him to wait inside the house till Damodaran is back. It is evident that Sreedharan doesn't want to be alone with a woman in a house. Vilasini has already told us that Sreedharan was a terribly shy person who wouldn't even look at a woman's face. The image of Sreedharan that we encounter in the first part of the film is as someone who is an ascetic. In the narratives by others also, Sreedharan comes across as someone who is not interested in worldly pleasures. From the factory owner's henchman's narrative, we find that Sreedharan is not persuaded by money or personal benefits either. This is where the narratives around Sreedharan, the revolutionary, have much in common with the prototype of the revolutionary. 
Writing in the context of the communist movement in West Bengal, Rajarshi Dasgupta argues that an ascetic masculinity is constitutive of the self-fashioning of a communist in India (Dasgupta, 2014, p. 74). Dasgupta sees "figures like the prophet and sufferer, the heretic and priestly, the confessor and the performer" as "important variations of the Communist ascetic and his practice of self-fashioning in India" (p. 74). The idea of suffering and renouncing the sense of individual self was central to the communist selfmaking. A communist was thought of as someone with no personal life and hence no personal loss. In the autobiographical writings of the early communist leaders in Kerala, a majority of whom come from the upper caste, we often come across the sufferings and sacrifices that they underwent in the process of transforming themselves as communists. Similarly, in the early communist melodramas like Ningalenne Communistakki and Mudiyanaya Puthran we see the heroes transforming themselves to communists. Through the melodramatic address, the early communist films in Malayalam, showed the communist hero as someone who is ascetic and selfless.

It is interesting to note that in the subjective narratives of the various people, it is the public life of Sreedharan that features. The incidents that feature in their recollection happen in public - be it the tea shop, in front of the factory where he sits on strike, the union office, outside Damodaran's house, etc. The public life of Sreedharan is the subject matter of the melodramatic narrative which constructs the heroic image of Sreedharan. At the same time, through his objective narrative interventions, the director shows the personal side of the communist hero. The objective narrative is an attempt to explore the interiority of Sreedharan. In this objective narrative we see, how the very first moment when Sreedharan is in close proximity with a woman, his desires come out. Savithri, a widow, whose father saved him and gave shelter after he was attacked, is applying steaming clothes on his wounds. Sreedharan makes advances at her, by holding her arms. A few moments ago he was unable to look at her face directly. Sreedharan feels guilty about what he did. When Savithri comes to his room again, after dinner, he apologizes to her. His head still hanging in shame, Sreedharan tells Savithri: "Savithri, you must forgive me. I should not have behaved that way with you. In a moment of weakness, I lost control of myself". The ascetic modality of the communist hero required the repression of desires, which comes out when in private. Through this scene, Gopalakrishnan suggest the crisis of masculinity which gets realigned as revolutionary masculinity.

As discussed before, Sreedharan is uncomfortable in the presence of Vilasini. With Savithri also, he is initially very uncomfortable and it is only after much hesitation that he makes an advance at Savithri. When Sreedharan apologizes, Savithri puts her hand on his shoulder and says, "Oh, it doesn't matter". It is interesting to note that after this incident, only once, and that is through the recollection of the factory owner's henchman that the revolutionary Sreedharan appears in the narrative in the first half of the film. The fall of the revolutionary, or the image of the revolutionary, seems to have started the moment when the public dimension of the revolutionary life ends and the domestic life starts. 
The relationship between Sreedharan and Savithri, the widow is cast in dubious lights. In popular discourses, the early communist leaders are often accused of having extra-marital relationships during their time in hiding. In fact, in the film Anubhavangal Paalichakal, an early communist melodrama, we see Chellappan trying to seduce Parvathy, the daughter of the Communist Party member who provided Chellappan shelter when he was in hiding. Though we do not see any romantic relationship between Sreedharan and Savithri, it is to Savithri that he eventually comes back. In Gopalakrishnan's portrayal of Sreedharan, while the public image of Sreedharan is an ascetic who has no interest in worldly pleasures, the "objective" narrative of the director, through the directorial address, brings in other aspects of Sreedharan's personality, which is contrary to the public image. It is in open or public spaces such as outside Damodaran's house, the union office, etc. that Sreedharan meets Vilasini. The director gives the hint that Sreedharan also has desires but he represses them for the sake of his public image. There is a sequence in the film when Vilasini goes back to the Union office after a meeting and asks the reason for his dislike for women. He evades the question by saying that he does not understand what she is speaking about. We see Sreedharn moving towards the window, after Vilasini leaves, and from the window he can see her leaving. Their eyes meet when Vilasini looks back but Sreedharan immediately withdraws, as if he is guilty of looking at her in that way. The next sequence in the film is Vilasini coming to the union office, another day, to invite Sreedharan for her wedding. When Vilasini comes, Sreedharan is burning a letter. The director creates a mystery around the letter: the letter must be a secret Party circular or a letter from a woman from his past.

After Sreedharan was beaten up, he was given shelter at Savithri's house. Savithri, who is a widow, is nursing Sreedharan. That is the first instance in the film where we see Sreedharan in a domestic or a private sphere. In the very first instance, he makes an advance at Savithri, for which he apologizes later. What is to be noted here is the stark contrast between the restrained public self that Sreedharan maintains and the desire that he expresses when he is in the domestic sphere. The realignment of masculinity that the revolutionary image demands results in a repression of desires. In fact, this is very much part of the ascetic modality. The self-fashioning of the communist through the ascetic modality is presented here. In Mooladhanam, a political melodrama scripted by Thoppil Bhasi, we see how sacrifice is presented as a capital required for the well-being of the society. Similarly, the communist hero in Anubhavangal Paalichakal is someone who undertakes many personal sacrifices.

In the film we repeatedly hear various characters saying that nobody expected Sreedharan to come back. It is the image of Sreedharan, the ideal that everyone wanted. The Sreedharan who returns soon becomes an object of disgust and it is through a form of martyrdom that he is salvaged as a revolutionary figure. However, it is interesting to note that the only person who believes that Sreedharan will come back is Savithri and it is in fact to Savithri that Sreedharan comes back, though he does not show any interest in her. Unlike in the first part of the film where Sreedharan brings to existence "a people" through the strike at the tile factory, in the second half, we see the people who are utterly in 
confusion after the split within the Communist Party, looking up to the leader. The inversion of the relationship between Sreedharan, who is a theoretician as well as an activist, and the people, suggests the inability of the communist project to bridge the gap between the intellectuals and the people, and thus the national-popular will collapsing. The death at end of the film resurrects the image of Sreedharan as a revolutionary, the image that was constructed through the melodramatic narrative.

After Sreedharan's murder in the second half of the film, both factions of the Communist Party take out a combined rally. An old photograph of Sreedharan from his charismatic days is used in the final procession after Sreedharan is killed. It is as if the "real" Sreedharan who came back after ten years did not exist at all. The film suggests that the people do not want any memory of the real and they would rather resurrect the old ideal. This also points to the melodramatic representation of communism, where the melodramatic narratives remain which may also prevent an exploration of reality. The film may be seen as an attempt to bring the "real" to the discussion. It may be pointed out that Sreedharan is a hero/vanguard from outside. In that respect, he represents the early communist leaders who travelled to faraway places to strengthen the Communist Party. If we look at the narratives around the Kayyur revolt, one of the historic struggles in the history of communist movement, it is a school teacher from outside who instils revolutionary consciousness in the people of Kayyur. In the beginning of the film, the tea shop owner tells Sreedharan that many people had tried to form a union, but in vain. Sreedharan, an outsider, succeeds to an extent in his attempt to form a trade union.

The Sreedharan that we encounter through the narratives of others in the first half of the film is a charismatic leader whereas in the second half he is presented as someone who is always drunk and as someone who has become a burden for everyone around. This Sreedharan even steals money from his wife for buying alcohol. He has shattered the hopes of everyone, as the tea shop owner tells him. Sreedharan comes back at a time when there is utter confusion among people, following the split within the Communist Party. The people have great faith in the coming back of Sreedharan. What is interesting to note here is that people are shown as looking up to the image of Sreedharan, the hero, who will offer redemption. Sreedharan returns to an unhappy land, which is waiting for a hero to emancipate them.

The individuals fail to construct themselves as a people who can collectively fight for their own emancipation. Thus the people in the film are not active political agents, but people looking for a hero. Gopalakrishnan's critique is that instead of taking responsibility for their own actions and predicaments, they are investing their hopes on the imaginary leader. The murder at the end of the film helps resurrect the revolutionary image of Sreedharan. Put differently, Sreedharan is again reinstated into the image and the image thus blurs the reality. The film seems to ask whether the image gained primacy over the real, which in turn prevented one from a detailed analysis of the failure of communism in Kerala. 
I argue that the film follows the same narrative strategy that Gopalakrishnan adopted in his first film Swayamvaram. While the "real" was juxtaposed with the "fantasy" in Swayamvaram, in Mukhamukham Gopalakrishnan devotes the first half of the film to show the "unrealness" of the revolutionary figure. The title of the film suggests a face-toface with reality in the second half where the "real" is juxtaposed with the "unreal" in the first half. However, in the first half of the film itself, Gopalakrishnan gives glimpses about the "real" nature of the revolutionary. It is through inserting realism through the objective narratives to the otherwise melodramatic recollections of people that Gopalakrishnan attempts a critique of the melodramatic representation of communist history and the communist hero. This is achieved in a marked difference from the revolutionary masculinity of Krishna Pillai. Sreedharan is shown as someone who consumes alcohol as a remedy for stomach ache, and as someone who survives on beedi and black tea. The communist activists have often been accused of having "illicit" relationships while in hiding. In a highly moralistic society like Kerala, this was seen as a major issue. That could be one of the reasons why there was a strong outrage against the portrayal of Sreedharan as an alcoholic and someone with extramarital relationships. As some critics have pointed out, the letters that Sreedharan burns in the presence of Savithri also create suspicion among the spectators about a possible marital relationship that Sreedharan has somewhere else. What emerges from this discussion is that the portrayal of the revolutionary figure Sreedharan as someone who takes refuge in alcohol goes against the revolutionary masculinity produced by narratives from the Left. What Gopalakrishnan's narrative strategy tries to achieve is to show the unrealness of the image created around the revolutionary from the beginning itself. I argue that communism itself was a melodramatic experience in Kerala in the mid-twentieth century and that Gopalakrishnan is privileging cinematic realism over melodrama to show what he sees as the faultline in the way communism was understood in Kerala.

This takes us to the debates around the question of how a revolutionary should be portrayed. In his critique of Thoppil Bhasi's landmark play Ningalenne Communistakki, E.M.S. Namboodiripad observed that the communist leaders in Communistakki were shown not as ordinary human beings, but as flawless characters (Namboodiripad, 1998). Adoor Gopalakrishnan makes a similar response. He says that he was telling the story of a human being with flaws. Responding to the allegations about showing Sreedharan consuming alcohol, Gopalakrishnan says that those who find fault with such a portrayal want to see Sreedharan as a flawless person, which is not the real case. He asks how one should portray communism and asserts that he is not interested in the way some commercial movies portray communism. Here Gopalakrishnan could be alluding to the socalled "red films" like Angadi (The Market) and Ee Nadu (This Land) of the I.V. Sasi-T. Damodaran duo that had appeared a few years before Mukhamukham or the early "Communist films" of the KPAC tradition. Let us look at how Gopalakrishnan talks about representing the communist hero. He writes:

What if I wanted to make a "revolutionary film" which everybody would accept? The character of Sreedharan should not have any distinct characteristics or individuality. 
Since Hindu gods have their own shortcomings one cannot portray him as equal to gods. What can be done then? We can give him the image of the "good" person then. Otherwise, how will a large majority of the people in this country approve of such a character? In order to show that he led a revolutionary mass organization one can also add revolutionary songs. At least five songs should be there in the first half of the film. Along with titles, one can also employ chorus which will create adrenalin rush in the audience. The hero should not be as fat or old as Sreedharan. Weren't early communists all slim and handsome! Where have I reached now with these descriptions? Isn't this a description of the film Punnapra Vayalar, a "revolutionary" film everybody appreciated!! Sorry I am not interested in making such a film (Gopalakrishnan, 1984, p. 13).

In these words, Gopalakrishnan is offering a critique of the melodramatic representation of Communism and the Communist hero in popular Malayalam cinema. It may be argued that through the film Mukhamukham Gopalakrishnan is attempting a critique of such melodramatic techniques. Gopalakrishnan states: "I had portrayed Communist workers as they are- men with the same emotions and weaknesses of fellow human beings, and I had never intended to defame or misrepresent the movement" (qtd in Bhaskaran, 2010, p. 132).

I have suggested how the film offers a critique of the melodramatic structures of the construction of the communist hero. The film's critique of the melodramatic representation of communism in Kerala provides us with an occasion for looking at the communist popular cultural practices as well. Let us briefly look at the way the communist hero was constructed in Malayalam cinema. Writings on early Malayalam cinema have often pointed out the absence of the mythological films in the industry. From the beginning, Malayalam cinema was characterized by the genre of the "social". Neelakkuyil, one of the early Malayalam films, offers a vision of a modern Kerala of rational subjects. It is through a melodramatic narrative that the character of postman, played by P. Bhaskaran who himself was a Communist Party member, was constructed.

While communist-inspired themes like equality, social justice, etc. had found place in Malayalam cinema, at a later stage many films with communism or communist hero at the centre of narrative were produced. Punnapra Vayalar on the historical peasant uprising of the people of Travancore; Mooladhanam (Capital) scripted by Thoppil Bhasi based on his own play of the same title; Anubhavangal Paalichakal (Shattered Experience), scripted by Thoppil Bhasi based on Thakazhi Sivasankara Pillai's novel of the same title are some of the films that dealt with communist themes or communist heroes in the late 196os and early 1970 s which was still a moment of hope about the Communist project in Kerala. In the 1970s, which was characterized by radical Left politics and the National Emergency, films like Kabani Nadi Chuvannappol (When the River Kabani Turned Red) which talked about a Naxalite revolutionary appeared. Around this time, there also appeared what is often described as "red" or "mass" films of the I.V. Sasi-T. Damodaran duo. 
It is interesting to compare Mukhamukham with the film Anubhavangal Paalichakal, a film scripted by Thoppil Bhasi, whose films had contributed to a certain kind of melodramatic construction of Communism. In Anubhavangal Paalichakal, Chellappan (played by Sathyan) is a respected local communist leader in public. However, he is suspicious of his wife's fidelity. He is forced to go into hiding as a result of his alleged involvement in a murder. The party arranges the house of a party worker in a nearby village for him to hide. Chellappan lives there under the name Prabhakaran. The party worker's daughter Parvathy (played by KPAC Lalitha) falls in love with Prabhakaran. One night, Prabhakaran makes sexual advances at her, but she resists. Feeling guilty about this, Chellappan suddenly realizes that he has been neglecting his family for long. He goes to his village without being noticed by anyone. However, he realizes that his wife is now living with his friend Gopalan (played by Prem Nazir), about whom Chellappan had been suspicious. Learning that his daughter has died, Chellapapn goes to the town where he beats up the goons who were trying to disrupt the strike of the workers of the factory. Eventually, Chellappan is arrested in connection with the murder of the factory owner and eventually sentenced to death.

It is Hamza, (played by Bahadoor), who runs a tea shop near the factory who first recognizes Chellappan as a revolutionary when others accuse him of being a goon of the factory owner. It is his contact with Hamza that gives Chellappan an idea about what is happening in the town. Hamza remains a friend of Chellappan throughout and even when Chellappan is hanged Hamza waits outside the jail. In Mukhamukham, it is the tea shop owner who is the first contact of Sreedharan. Kuttan Pillai, the tea shop owner is the first one to go to meet Sreedharan on his return in the second half of the film. It is the same tea shop owner who tells Sreedharan towards the end of the film that Sreedharan has let everyone down. Even though the tea shop owner has refrained from making any "political" comments other than his occasional remark that "only crooks and cheats can prosper these days", it is, in fact only through the tea shop owner that Gopalakrishnan is trying to articulate certain class questions in the film.

\section{Conclusion}

In the context of the political violence in the Kannur district of Kerala, Dilip Menon has pointed out the centrality of notions of martyrdom in the construction of the political tradition of the Left in Kerala (Menon, 2016). As I have noted before, in Mukhamukham, it is only through the murder of Sreedharan that the revolutionary image of Sreedharan can be resurrected. There is an interesting narrative strategy that Gopalakrishnan adopts here. When we look at the martyrs in the communist political melodramas, the martyrdom is achieved through a fight with the ruling forces. In Anubhavangal Paalichakal, for instance, it is the murder of the factory owner, the class enemy that leads to Chellappan's martyrdom. Similarly, in Mudiyanaya Puthran, we see Rajan going to the jail for the murder of a class enemy. In Mukhamukham, however, the murder of the factory owner does not result in any martyrdom, but only in the disappearance of the communist hero. The martyrdom in the 
film is one that is constructed by taking recourse to the earlier revolutionary image of Sreedharan.

\section{References}

Backer, P.A. (1975). Kabani Nadi Chuvannappol [Motion picture]. India: Malayalam.

Bhasi, Thoppil. (1970). Ningalenne Communistakki [Motion picture]. India: Malayalam.

Bhaskaran, Gautaman. (2010). Adoor Gopalakrishnan: A Life in Cinema. Penguin India.

Bhaskaran, P. (1969). Mooladhanam [Motion picture]. India: Malayalam.

Bhaskaran, P., and Ramu Kariat. (1954). Neelakkuzhil [Motion picture]. India: Malayalam.

Dasgupta, Rajarshi. (2014). "The Ascetic Modality: A Critique of Communist Self-fashioning”. In Nivedita Menon, Aditya Nigam and Sanjay Palshikar (Eds.), Critical Studies in Politics: Exploring Sites, Selves, Power. Orient Blackswan,

Gopalakrishnan, Adoor. (1972). Swayamvaram [Motion picture]. India: Malayalam.

Gopalakrishnan, Adoor. (1978). Kodiyettam [Motion picture]. India: Malayalam.

Gopalakrishnan, Adoor. (1981). Elippathayam [Motion picture]. India: Malayalam.

Gopalakrishnan, Adoor. (1984). Mukhamukham [Motion picture]. India: Malayalam.

Gopalakrishnan, Adoor. (1984, 30 December). “Whose failure? The film's or the critic's?” Mathrubhumi Weekly.

Gopalakrishnan, Adoor. (1985). “The Director about the Film.” In Shampa Banerjee (Ed.), Face to Face. Seagull Books,

Kariat, Ramu. (1961). Mudiyanaya Puthran [Motion picture]. India: Malayalam.

Kunchakko. (1968). Punnapra Vayalar [Motion picture]. India: Malayalam.

Mani, M.S. (1961). Puthiya Akasam Puthiya Bhoomi [Motion picture]. [Motion picture]. India: Malayalam.

Menon, Dilip. (2016). "A Prehistory of Violence? Revolution and Martyrs in the Making of a Political Tradition in Kerala”. South Asia: Journal of South Sian Studies, 39.3.

Namboodirippad, E.M.S. (1998). "Paattabakki Muthal Ningalenne Communistakki Vare” (From Paattabakki to Ningalenne Communistakki). In E.M.S. Namboodiripad, (Ed.), Theranjedutha Prabandhangal (Selected Essays). Kerala Sahitya Academy.

Radhakrishnan, Ratheesh. (2006). Masculinity and the Structuring of the Public Domain in Kerala: A History of the Contemporary. Unpublished Ph.D. Thesis. Bangalore: Centre for the Study of Culture and Society.

Sasi, I.V. (1980). Angadi [Motion picture]. India: Malayalam.

Sasi, I.V. (1982). Ee Nadu [Motion picture]. India: Malayalam.

Sethumadhavan, K.S. (1971). Anubhavangal Paalichakal [Motion picture]. India: Malayalam.

Swart, Patricia L. (2012). Politics, gender, spectators: An ethnographic exploration of the Malayalam cinema of Kerala. Unpublished Ph D Dissertation, New School University.

P. Muhammed Afzal is an Assistant Professor of Cultural Studies in the Department of Humanities and Social Sciences, Birla Institute of Technology and Science, Pilani (BITS Pilani), Pilani, Rajasthan. His areas of research interests include Malayalam Cinema, Intellectual and Cultural History of the Left in India, Popular Culture and Popular Politics, Cultural Studies in Asia, and Language Politics. 